\title{
Removal of Cd (II) ions from Aqueous Solution by Adsorption on Activated Carbon Prepared from Lapsi (Choerospondias axillaris) Seed Stone
}

\author{
Rajeshwar Man Shrestha \\ Department of Engineering Science and Humanities, Institute of Engineering, Tribhuvan University, Nepal \\ corresponding author: rajeshwar@ioe.edu.np
}

\begin{abstract}
Batch adsorption experiments were conducted for the adsorption of $\mathrm{Cd}$ (II) ions from aqueous solution by activated carbon prepared from Lapsi seed stone. The activated carbon was characterized by Iodine number, Methylene blue number, SEM and FTIR. Adsorption experiments were carried out to describe the effect of $\mathrm{pH}$ ,contact time and adsorbent dose on the metal ion removal process. The results showed that the adsorption of $\mathrm{Cd}$ (II) ions was very fast initially and the equilibrium time was $3 \mathrm{hrs}$. The $\mathrm{pH}$ of 6.0 was an optimal $\mathrm{pH}$ for adsorption of $\mathrm{Cd}(\mathrm{II})$ ions. Langmuir and Freundlich adsorption isotherms were used to explain the equilibrium data. Langmuir model best described the data with higher value of coefficient of determination as compared to that of Freundlich isotherm showing a maximum uptake of $37.0 \mathrm{mgg}^{-1}$. This study demonstrated that the activated carbons prepared from Lapsi seed stone could be used for the removal of $\mathrm{Cd}$ (II) ions in water treatment.
\end{abstract}

Key words: Adsorbent, Adsorption isotherm, Adsorption capacity, Lapsi seed stone, Cadmium

\section{Introduction}

The contamination of water by toxic heavy metals is a worldwide environmental problem. Cadmium $(\mathrm{Cd})$ is a major toxic heavy metal and introduced into the bodies of water from smelting, metal plating, cadmium-nickel batteries, phosphate fertilizer, mining, pigments, stabilizers, alloy industries and sewage sludge. The toxic heavy metal may cause cancer, lung fibrosis, chronic disorders such as "itai -itai", renal damage, hypertension, testicular atrophy, dyspnea and weight loss to human beings [1]. It accumulates in the human body especially in kidneys, thus leading to disfunction of the kidney. Thus, $\mathrm{Cd}$ has been included in the red list of priority pollutants by the Department of Environment, UK and in the black list of Dangerous Substance Directive in European Economic Community. US Environment Protection Agency has also classified Cd as group B1 carcinogen [2].The permissible limit for $\mathrm{Cd}$ in drinking water guideline value recommended by World Health Organization (WHO) is $0.003 \mathrm{mg} / \mathrm{L}$. It should therefore be removed before discharge.

Various treatment technologies exist for removal of heavy metals from water, including chemical precipitation, ion exchange, membrane filtration, electrochemical treatment. Application of such technologies mentioned is restricted because of technical or economical constraints. Hence, adsorption as one of the most popular and effective technologies, has been widely studied over recent decades, because of its high efficiency, easy handling, and availability of different adsorbents. Adsorption process has been exclusively in water treatment and many studies has been carried out to find the inexpensive and chemico-physiccaly feasible adsorbent. Many reports explored the 
development of low cost activated carbon from cheaper and readily available materials . There are a quite large number of studies regarding the preparation of activated carbons from agricultural wastes [3], fruit stones [4], hard shell of fruit stones [5], oil palm waste [6], agricultural residue from sugarcane [7], rice husk [8], peanut[9], sawdust [10], coconut shell [11], palm shell [12], hazelnut husks [13] etc. have been tested in the production of activated carbon in developing countries. The use of these raw materials in carbon production shows from the past studies that they are available at low cost, contain high carbon content and may be effective in the removal of heavy metals. Number of fruit stones such as cherry stones, apricot stones [14], olive stones [15], dates stones [16], peach stones [17], sea-buckthorn stones etc. have also been used for the production of activated carbons.

In this current study, activated carbon prepared from Lapsi seed stones has been used for the removal of Cd (II) ions from aqueous solution since the seed stones are readily available and can be used as a viable adsorbent for the removal of heavy metals. Lapsi seed stone is the waste product of Lapsi fruits. Lapsi (Choreospondias axillaris) belongs to the family Anacardiaceous. It is a large, fruit bearing deciduous tree native to the hills of Nepal (865-1900m). Lapsi fruit is consumed fresh, pickled or processed into a variety of sweet and sour fruit products locally called "Mada" or "Titaura". It is a rich source of vitamin C. It is also believed to aid in digestion and is often consumed after a protein rich meal. Seed stones are used as fuel in brick kilns in the factories and the trunk of the tree is used as fuel wood and timber $[18,19]$. The objective of the current study is to examine the effectiveness of prepared activated carbon for adsorption of Cd (II) ions from aqueous solution at room temperature.

\section{Material and Methods}

\subsection{Preparation of Adsorbent}

Seed stones of Lapsi fruits are the precursors used for the preparation of activated carbon in this study.Lapsi fruits were collected from Kalimati market, Kalimati, Kathmandu. The fruits were stripped for the pulp by boiling to expose rigid centres or stones. The seed stones were washed several times using tap water and then distilled water to remove impurities, dried at $110^{\circ} \mathrm{C}$ for 24 hours and crushed with mortar and grinded with electric grinder. The crushed particles were then sieved to obtain the fraction $300 \mu \mathrm{m}$. The particles were mixed with $50 \% \mathrm{H}_{3} \mathrm{PO}_{4}$ in the ratio of $1: 1$ and dehydrated at $100{ }^{\circ} \mathrm{C}$ for 24 hours in a hot box oven and then carbonized at $400{ }^{\circ} \mathrm{C}$ for four hours in a horizontal tubular furnace under flow $(75 \mathrm{ml} / \mathrm{min})$ nitrogen. The resultant activated carbon was cooled at room temperature and was washed several times with hot distilled water. The material was then dried at $110^{\circ} \mathrm{C}$ for 24 hours, cooled and sieved to obtain the particles of size $106 \mu \mathrm{m}$. The activated carbon was indicated as PALC (Phosphoric acid activated Lapsi seed stone carbon) and used for adsorption study.

\subsection{Chemicals and Instruments}

All chemicals and reagents were of analytical grade (Merck and Qualigens Company). Stock solutions of $\mathrm{Cd}$ (II) ions were prepared from cadmium nitrate in distilled water. In order to measure the $\mathrm{pH}$ values of the solutions Digital $\mathrm{pH}$ meter was used. The adsorption experiments were carried out by using Shaker (Digital VDRL Rotator-RPM-S). The concentrations of Cd(II) ions were determined by atomic absorption spectrophotometer (AAS -VARIAN-AA240FS). Solutions of $0.1 \mathrm{M} \mathrm{NaOH}$ and $0.1 \mathrm{M} \mathrm{HCl}$ were used for $\mathrm{pH}$ adjustment. All the working solutions were prepared by diluting the stock solutions with distilled water. 


\subsection{Adsorption Experiments}

Batch experiments of adsorption were performed in $50 \mathrm{ml}$ stoppered conical flasks .The flasks were being agitated on Digital VDRL Rotator- RPM-S at $225 \mathrm{rpm}$ for identified time intervals. The effect of contact time, adsorbent dose and solution $\mathrm{pH}$ was studied. Each experiment was carried out by suspending $0.05 \mathrm{~g}$ of adsorbent in $25 \mathrm{ml}$ adsorbate solution taken in the conical flasks under the optimum conditions set out for the experiments. Since $\mathrm{pH}$ is a critical parameter in the process; therefore $\mathrm{pH}$ of the solutions was adjusted by addition of $\mathrm{NaOH}$ and $\mathrm{HCl}$.The effect of $\mathrm{pH}$ and contact time on the adsorption of Cd (II) ions by PALC at different $\mathrm{pHs}$, contact time and adsorbent dose was studied using $25 \mathrm{ml}$ of $\mathrm{Cd}(\mathrm{II}) 50 \mathrm{mg} \mathrm{L}^{-1}$ at room temperature.

The amount of metal ions adsorbed can be calculated by the following equation.

$$
\mathrm{q}_{\mathrm{e}}=\frac{\left(\mathrm{C}_{\mathrm{o}}-\mathrm{C}_{\mathrm{e}}\right)}{\mathrm{W}} \times \mathrm{V}
$$

Where $\mathrm{C}_{\mathrm{o}}$ and $\mathrm{C}_{\mathrm{e}}$ are initial and equilibrium concentration of metal ion $(\mathrm{mg} / \mathrm{L})$ respectively, $\mathrm{W}$, the mass of adsorbent in gram $(\mathrm{g})$ and $\mathrm{V}$ is the volume of the solution in litre (L).

The percentage of removed metal ions (Rem \%) in solution is calculated by using following the formula

$$
\operatorname{Rem}(\%)=\frac{\left(\mathrm{C}_{\mathrm{o}}-\mathrm{C}_{\mathrm{e}}\right)}{\mathrm{C}_{\mathrm{o}}} \times 100
$$

\section{Results and Discussion}

\subsection{Effect of $\mathrm{pH}$}

The $\mathrm{pH}$ of the aqueous solution plays an important role and influences on the metal speciation in aqueous solution as well as the surface properties of adsorbent and therefore can affect the extent of adsorption [20] . So the adsorption behavior of Cd (II) ions on PALC has been studied over a $\mathrm{pH}$ range of 2-7 at room temperature. The percentage removal of removal of metal ions against $\mathrm{pH}$ is shown in Figure 1. The percentage removal of metal ions increases with increase in $\mathrm{pH}$ and attains plateau value at $\mathrm{pH}$ range of 6-7. The metal ions get precipitated above $\mathrm{pH} 7$ so adsorption experiments above this $\mathrm{pH}$ were not studied. The percentage of removal of Cd (II) is low at low $\mathrm{pH}$. This lower percentage removal of the metal ions may be due to the fact that at lower $\mathrm{pH}$ there is higher concentration of hydrogen ions and that competes with metal ions. Owing to this the percentage removal of metal ions from aqueous solution is low.

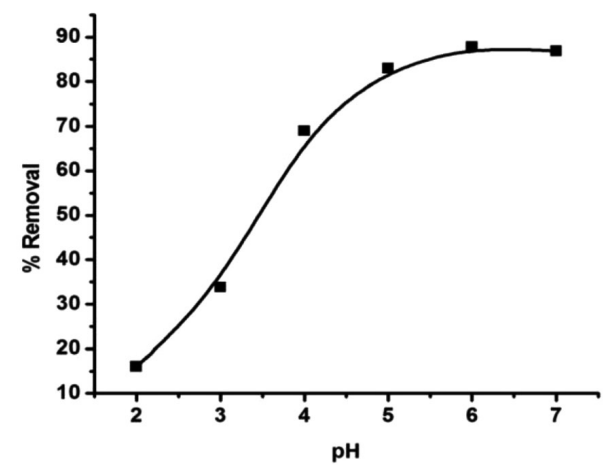

Figure 1 Effect of $\mathrm{pH}$ on the adsorption of $\mathrm{Cd}(\mathrm{II})$ ions

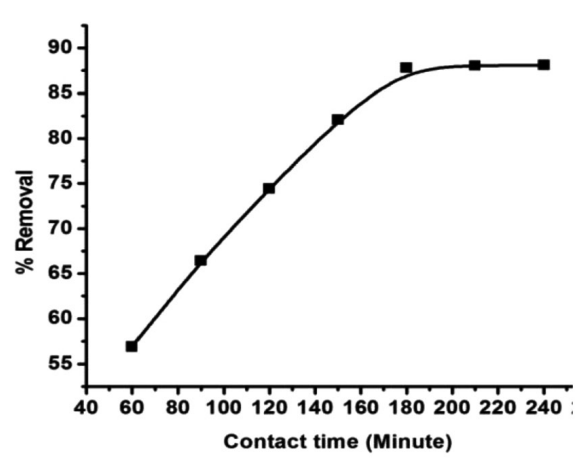

Figure 2 Effect of adsorbent dose on the adsorption of $\mathrm{Cd}(\mathrm{II})$ ions 
Moreover at higher $\mathrm{pH}$, the acidic surface functional groups (eg $-\mathrm{COOH},-\mathrm{OH}$ etc.) present on carbon surface produces -vely charged surface sites due to the shift in the equilibrium of ionization of acidic functional groups and at this -vely charged site adsorption of metal ions take place.

\subsection{Effect of Contact time}

The plot of percentage removal of Cd(II) ions onto PALC against time is shown in Figure 2. The percentage removal of the metal ions increases with increase in time and attains a maximum value at about 180 minutes. The adsorption rate is very fast initially up to 100 minutes and then after it attains equilibrium value slowly. The fast adsorption at initial stage may be due to the higher driving force owing to the availability of the large concentration of active sites for adsorption. After 100 minutes the removal percentage increases gradually and attains plateau value at 180 minutes. At equilibrium all the active sites will be covered by the metal ions and no further adsorption of metal ions takes place. Thus equilibrium time for adsorption of $\mathrm{Cd}(\mathrm{II})$ ions is about 3 hours.

\subsection{Effect of Adsorbent dose}

The plot of percentage removal against adsorbent dose is shown in Figure 3. The percentage removal increased with increase in adsorbent dose from $0.5 \mathrm{~g} / \mathrm{L}$ to $2 \mathrm{~g} / \mathrm{L}$. The increase in percentage removal of metal ions with an increase in adsorbent dose is obviously due to the availability of larger adsorption sites due to increase in adsorbent dose The percentage removal of the heavy metal ions remains constant when adsorbent dose is more than $2 \mathrm{~g} / \mathrm{L}$. Adsorbent dose of $2 \mathrm{~g} / \mathrm{L}$ is sufficient for effective removal of $\mathrm{Cd}(\mathrm{II})$ ions from the aqueous solutions.

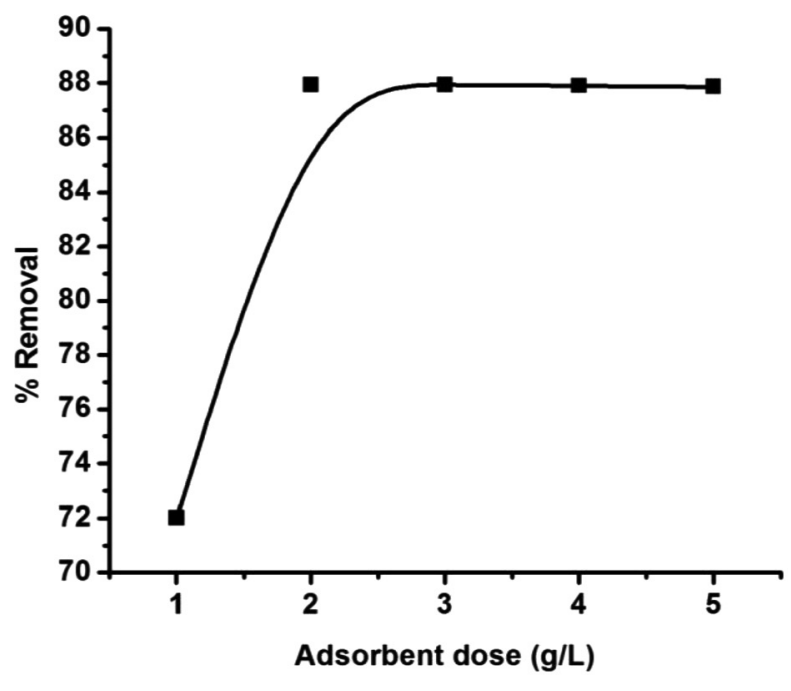

Figure 3 Effect of Adsorbent dose on the adsorption of Cd (II) ion

\subsection{Surface chemistry}

\subsubsection{Fourier Transform Infrared (FTIR) Spectroscopy}

The FTIR spectra of carbon without activating agent (Raw carbon), dried unloaded activated carbon (PALC) and Cd(II) loaded activated carbon were examined to study the effect of activating agent in the production of surface functional groups and were presented in Figures 4,5 and 6 
respectively. The FTIR spectra of unloaded activated carbon exhibit a broad band at $3419 \mathrm{~cm}^{-1}$ due to the presence of hydroxyl groups on the adsorbent surface. The band located at $1725 \mathrm{~cm}^{-1}$ is ascribed to the stretching vibrations of carboxylic groups or to conjugated carbonyl groups $(\mathrm{C}=\mathrm{O}$ in carboxylic and lactones groups). Asymmetric stretching vibrations of ionic carboxylic groups (-COO-) appeared at $1571 \mathrm{~cm}^{-1}$. The FTIR of raw carbon as shown in Figure 4 has no such bands. Comparing the raw and activated carbon, the bands $1725.0 \mathrm{~cm}^{-1}$ and $3419.0 \mathrm{~cm}^{-1}$ were observed in activated carbon but they were not seen in raw carbon. The presence of these bands in activated carbon is due to the action of activating agent in functionalizing the carbon during its preparation. Similarly comparing Cd(II) unloaded activated carbon with CdII) loaded activated carbon the bands at $3419.0 \mathrm{~cm}^{-1}$ and $1571 \mathrm{~cm}^{-1}$ were shifted to higher wave numbers $3454.32 \mathrm{~cm}^{-1}$ and $1587 \mathrm{~cm}^{-1}$ respectively and whereas $1725 \mathrm{~cm}^{-1}$ band was disappeared in CdI) loaded activated carbon. This indicates that the functional groups were involved in the adsorption of $\mathrm{Cd}(\mathrm{II})$ ions onto the activated carbon.
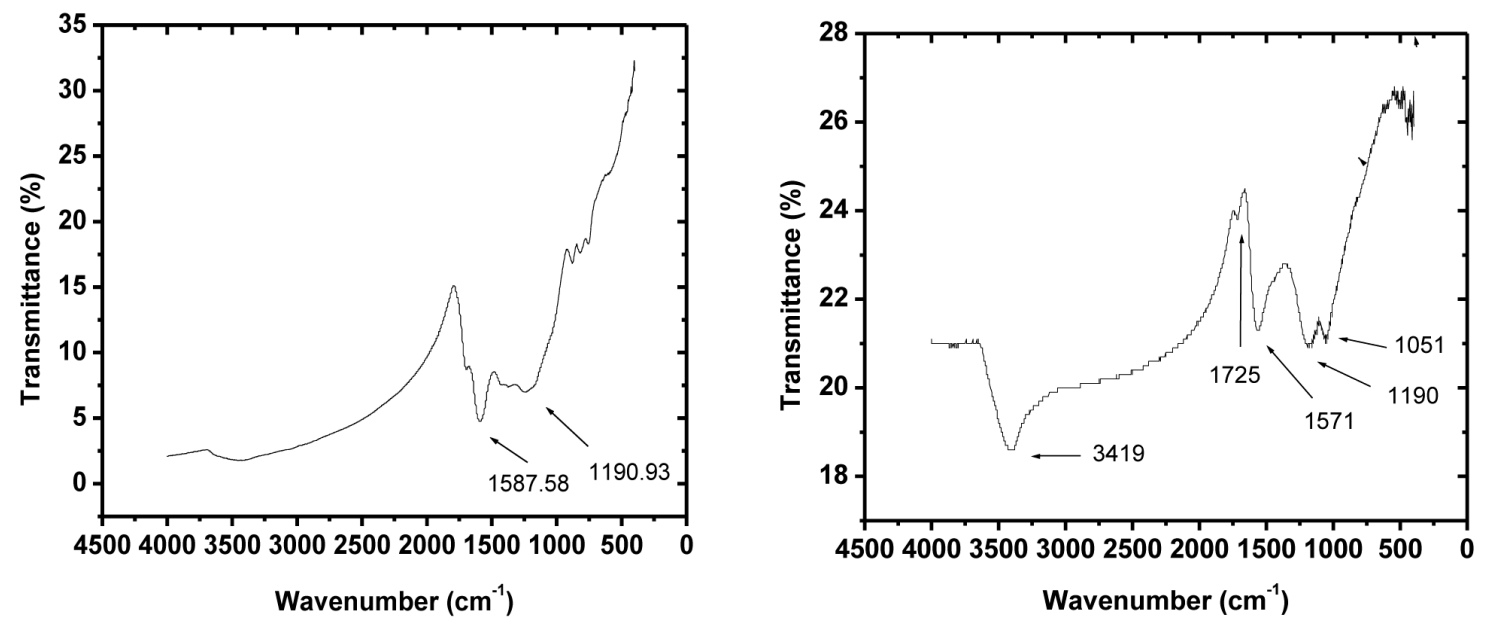

\subsubsection{Boehm titration (Surface functional group determination)}

To determine the concentration of acidic functional groups Boehm titration was performed. The milli-equivalent of different acidic functional groups present in activated carbon prepared by thermal carbonization at $400^{\circ} \mathrm{C}$ (PALC), are presented in Table 1. The activated carbon (PALC) contains carboxylic, phenolic and lactone surface functional groups

Table 1 Boehm titration results of PALC

\begin{tabular}{|c|c|c|c|}
\hline \multirow{2}{*}{ Adsorbent } & \multicolumn{3}{|c|}{ Functional groups in mill equivalent per gram(meq/g) } \\
\cline { 2 - 4 } & Carboxyl & Phenolic & Lactones \\
\hline PALC & 0.9 & 0.6 & 0.7 \\
\hline
\end{tabular}

\subsubsection{Scanning Electron Microscope (SEM)}

Scanning Electron Microscope (SEM) of the carbons prepared without activating agent and with $\mathrm{H}_{3} \mathrm{PO}_{4}$ as activating agent with different concentrations is presented in Figure 7. Figure 7(a) is the SEM of carbon prepared from Lapsi seed stone without any activating agent. The surface is heterogeneous and hardly any pores are visible. Figure 7 (b) is the SEM images of activated 
carbon prepared by using $\mathrm{H}_{3} \mathrm{PO}_{4}$ as activation agent. In the SEM image (b) a number of pores with different diameters are observed. This development of porous structure may be attributed to the dehydrating effect of $\mathrm{H}_{3} \mathrm{PO}_{4}$. Phosphoric acid being a strong dehydrating agent removes oxygen and hydrogen from lignocellulosic material as water, and that promotes the development of porous structure.

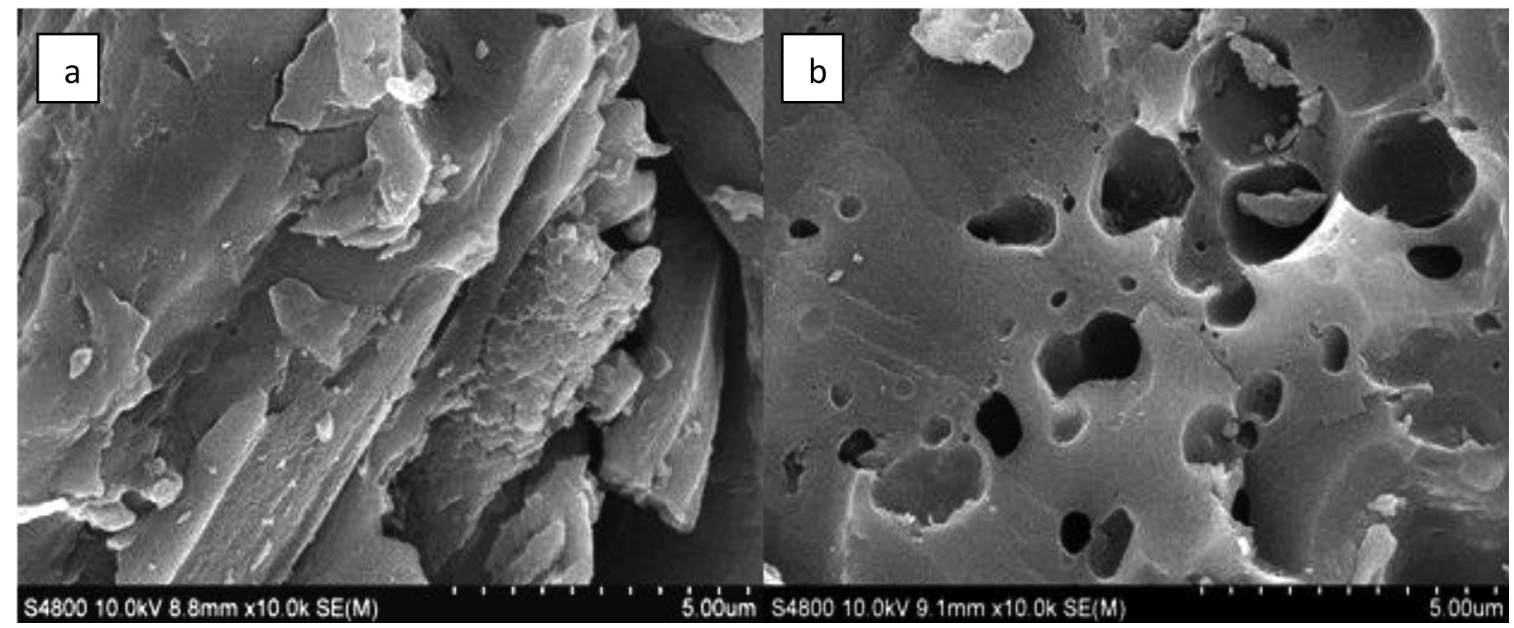

Figure 7 SEM Photographs of (a) carbon prepared without activating agent (Raw carbon) (b) activated carbon prepared using $50 \% \mathrm{H}_{3} \mathrm{PO}_{4}$ [Carbonization time: $4 \mathrm{hr}$; ratio of LSSP: $\mathrm{H}_{3} \mathrm{PO}_{4}=1: 1$ ]
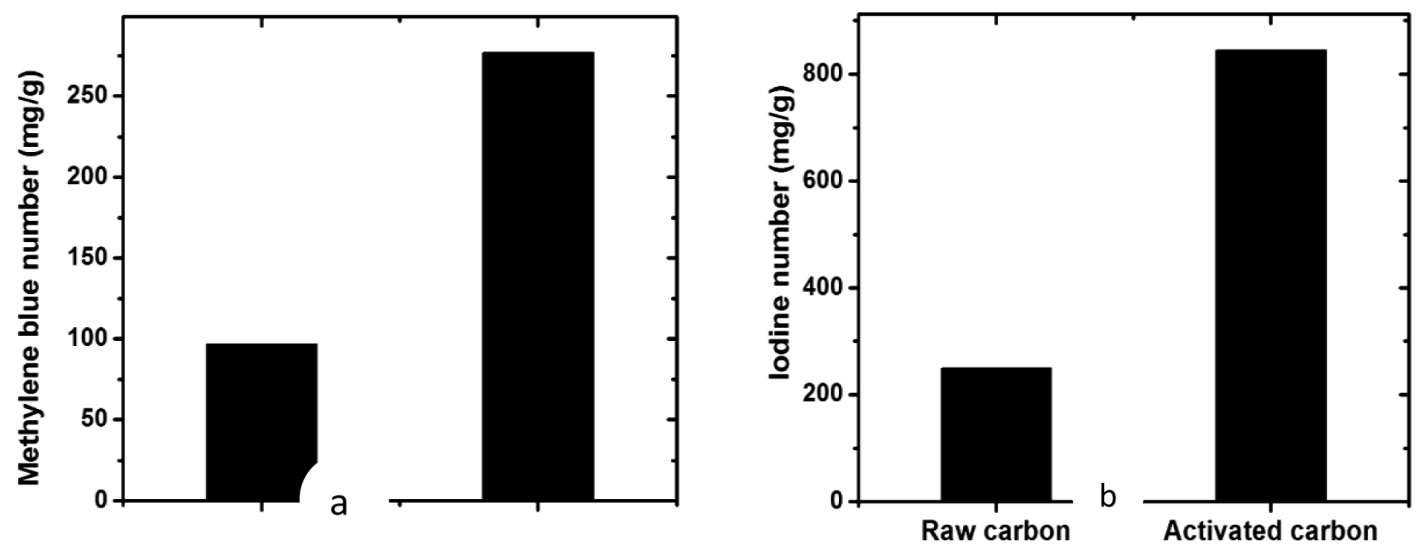

Figure 8 (a)Methylene blue number and(b)Iodine number of Raw carbon and activated carbon

\subsubsection{Iodine number and Methylene blue number}

Iodine number gives approximate measure of the micropore content while methylene blue number indicates mesopore distribution in the activated carbon. Iodine number and Methylene blue numbers are used to estimate approximate surface area and concentration of micro and mesopores. The iodine number is defined as the amount of iodine adsorbed per gram of activated carbon at an equilibrium concentration. Methylene blue number is defined as the amount of the dye adsorbed by one gram of the adsorbent. Methylene blue number gives useful indication to evaluate the adsorptive capacity of activated carbon in batch mode. Iodine being small molecules enters into micropores while methylene blue being a big molecule is absorbed into the mesopores. The results showed that phosphoric acid played an important role to increase Iodine and Methylene numbers 
i.e. the increase in micropores and mesopores in activated carbon prepared as shown in Figure 8 (a) and (b). The formation of pores may be due to that fact that phosphoric acid being a strong dehydrating agent removes oxygen and hydrogen from lignocellulosic material as water, and that promotes the development of porous structure.

\subsection{Adsorption isotherm}

Adsorption isotherm indicates how the adsorption molecules distribute between liquid phase and solid phase when adsorption process attains an equilibrium state. Langmuir and Freundlich models are most frequently employed models. In this work, both models were used to describe the relationship between the amount of heavy metal (II) ions adsorbed and its equilibrium concentration in solution at laboratory temperature. The applicability of isotherm equation is compared by judging coefficients of determination $\left(\mathrm{R}^{2}\right)$ of Langmuir and Freundlich isotherms plots.

\subsubsection{Langmuir isotherm}

Langmuir assumed that adsorption occurs uniformly on the active part of the surface and when a molecule is adsorbed on an active site, the other molecules could not be interacted with this site. The linear form of Langmuir isotherm equation is given by

$$
\frac{\mathrm{C}_{\mathrm{e}}}{\mathrm{q}_{\mathrm{e}}}=\frac{1}{\mathrm{bq}_{\mathrm{m}}}+\frac{\mathrm{C}_{\mathrm{e}}}{\mathrm{q}_{\mathrm{m}}}
$$

Where $\mathrm{C}_{\mathrm{e}}$ is the equilibrium concentration of the adsorbate $(\mathrm{mg} / \mathrm{L})$ and $\mathrm{q}_{\mathrm{e}}$ is the amount of the adsorbate adsorbed under equilibrium while $\mathrm{q}_{\mathrm{m}}$ is the monolayer adsorption capacity $(\mathrm{mg} / \mathrm{g}$ ) and $\mathrm{b}$ is the Langmuir constant. The validity of Langmuir adsorption isotherm adsorption data of PALC is tested by plotting the value of $\mathrm{C}_{e} / \mathrm{q}_{\mathrm{e}} \mathrm{vs} \mathrm{C}_{\mathrm{e}}$. The typical plot $\mathrm{C}_{\mathrm{e}} / \mathrm{q}_{\mathrm{e}} v_{\mathrm{s}} \mathrm{C}_{\mathrm{e}}$ is shown in Figure 9 for adsorption of Cd(II) on PALC. The plot is found to be linear one with coefficient of determination $\left(\mathrm{R}^{2}\right)$ nearly equal to 1 indicating the validity of Langmuir adsorption isotherm. Langmuir constant (b) and maximum adsorption capacity $\left(\mathrm{q}_{\max }\right)$ are calculated from the slope and intercept of the plots which are given in Table 3 for adsorption of Cd (II) ions onto PALC .

Table 2 Adsorption capacities of Cd (II) ions by various adsorbents for comparison with that of PALC

\begin{tabular}{|l|c|l|}
\hline \multicolumn{1}{|c|}{ Adsorbents } & Adsorption capacity $\mathbf{q}_{\mathbf{m a x}} \mathbf{m g ~}^{-\mathbf{1}}$ & \multicolumn{1}{c|}{ References } \\
\hline Corn cob by $\mathrm{HNO}_{3}$ & 19.3 & Ramos et al., 2005 \\
\hline Juniper fibre by $\mathrm{NaOH}$ & 29.5 & Min et al., 2004 \\
\hline Spirodela polyrhiza & 36.0 & Meitei et al., 2013 \\
\hline PALC & 37.0 & This study \\
\hline
\end{tabular}




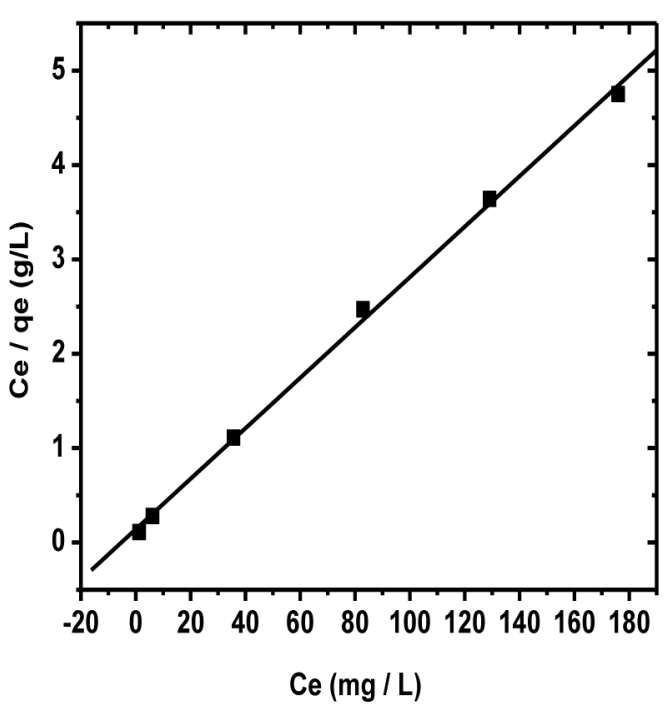

Figure 9.Langmuir adsorption isotherm of Cd (II) ions onto PALC

Adsorption capacity of cadmium as compared to that of other adsorbents is presented in Table 2 which shows that PALC has higher adsorption capacity than that of other adsorbents such as Corn cob by $\mathrm{HNO}_{3}$ Juniper fibre by $\mathrm{NaOH}$ and spirodela polyrhiza. Hence the PALC is better in the adsorption of $\mathrm{Cd}(\mathrm{II})$ in comparison to that of adsorbents like $\mathrm{HNO}_{3}$ treated corn cob, $\mathrm{NaOH}$ treated Juniper fibre and bioadsorbent spirodela polyrhiza.

\subsubsection{Freundlich isotherm}

Freundlich isotherm is an empirical equation which describes the heterogeneous adsorption and assumes that different sites with several adsorption energies are involved. Freundlich equation is shown below in its linear form.

$$
\log q_{e}=\log K_{f}+\frac{1}{n} \log C_{e}
$$

Where $\mathrm{K}_{\mathrm{f}}$ and $\mathrm{n}$ are Freundlich constants related to adsorption capacity and adsorption intensity respectively. In order to test the validity of Freundlich adsorption isotherm adsorption data of PALC are tested by plotting the value of $\log \mathrm{C}_{\mathrm{e}} \mathrm{vs} \log \mathrm{q}_{\mathrm{e}}$ as shown in Figure 10. Freundlich constant $\mathrm{K}_{\mathrm{f}}$ and $\mathrm{n}$ are determined from intercept and slope which are given in Table 3 for adsorption of $\mathrm{Cd}$ (II) ions onto PALC. Table 3 shows that the values of coefficient of determination for Freundlich adsorption isotherm are found to be less than that for Langmuir model. This means that adsorption of Cd (II) ions onto PALC follows Langmuir model better than Freundlich model. 


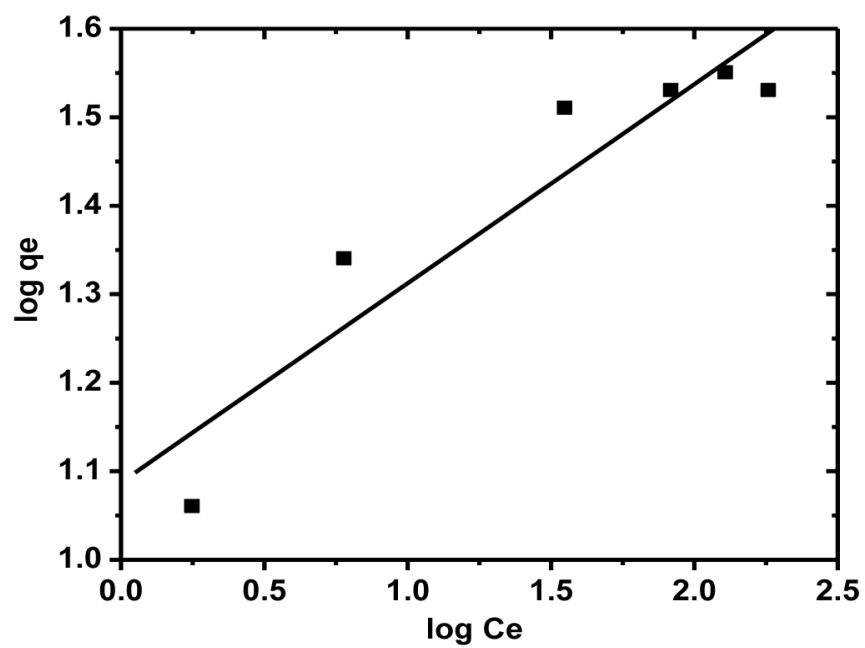

Figure 10 Freundlich adsorption isotherm of $\mathrm{Cd}(\mathrm{II})$ ions onto PALC

Table 3 Langmuir and Freundlich parameters for adsorption Cd (II) ions onto PALC

\begin{tabular}{|c|c|c|c|c|c|c|}
\hline \multirow{2}{*}{$\begin{array}{c}\text { Heavy metal- } \\
\text { ion }\end{array}$} & \multicolumn{2}{|c|}{ Langmuir parameters } & & \multicolumn{2}{|c|}{ Freundlich parameters } & \\
\cline { 2 - 3 } & $\left.\mathbf{q}_{\max } \mathbf{m g} / \mathbf{g}\right)$ & $\mathbf{b}$ & $\mathbf{R}^{\mathbf{2}}$ & $\mathbf{K}_{\mathbf{f}}(\mathbf{m g} \mathbf{g})$ & $\mathbf{( n )}$ & $\mathbf{R}^{\mathbf{2}}$ \\
\hline $\mathrm{Cd}(\mathrm{II})$ & 37 & 0.19 & 0.998 & 12.23 & 4.44 & 0.878 \\
\hline
\end{tabular}

Freundlich constant $\mathrm{K}_{\mathrm{f}}$ and $\mathrm{n}$ are determined from intercept and slope which are given in Table 3 for adsorption of Cd (II) ions onto PALC. Table 3 shows that the values of coefficient of determination for Freundlich adsorption isotherm are found to be less than that for Langmuir model. This means that adsorption of Cd (II) ions onto PALC follows Langmuir model better than Freundlich model.

\section{Conclusion}

Activated carbon prepared from Lapsi seed stone by chemical activation with phosphoric acid can be used as an adsorbent for removal of Cd (II) ions from aqueous solution. The adsorption of Cd (II) is found to be greatly dependent on the $\mathrm{pH}$ of sample solution. The optimum $\mathrm{pH}$ for the adsorption of $\mathrm{Cd}(\mathrm{II})$ ions onto PALC is found to be 6.FTIR and Boehm titration shows the presence of surface functional groups such as carboxyl, phenolic and lactone. SEM image of activated carbon exhibits pores of different diameters. Equilibrium data are in good agreement with Langmuir isotherm with higher value of coefficient of determination as compared to that of Freundlich isotherm, confirming the monolayer adsorption capacity of $\mathrm{Cd}$ (II) with adsorption capacity $37 \mathrm{mg} / \mathrm{g}$. The result demonstrated that the activated carbon prepared from Lapsi seed stone by one step phosphoric activation is expected to be economically feasible for the removal of Cd (II) ions from aqueous solutions

Acknowledgements: The author would like to express sincere gratitude to Prof. Dr. Raja Ram Pradhananga, Central Department of Chemistry, Tribhuvan University, Kathmandu for his continuous encouragement, motivation and invaluable suggestions. Acknowledgement also goes to Prof. Bhadra Prasad Pokharel, Department of Engineering Science and Humanities, Pulchowk campus, Institute of Engineering, Tribhuvan University and Assoc. Prof. Dr. Amar Prasad Yadav, Central Department of Chemistry, Tribhuvan University, for his encouragement and valuable 
suggestions. Thanks also go to Nepal Bureau of Standards and Metrology, Balaju, Kathmandu for the measurement of heavy metal ions by AAS.

\section{References}

[1] Liuchun Z, Zhi D, Xiaoyun Y and Hui Z (2010), Equilibrium and kinetic studies of adsorption of Cd (II) from aqueous solution using modified corn stalk. Journal of Hazardous Materials 176: $650-656$.

[2] Wang FY, Hui W and Jian WM (2010), Adsorption of cadmium (II) ions from aqueous solution by a new low-cost adsorbent—Bamboo charcoal. Journal of Hazardous Materials 177: 300 306.

[3] He ZY, Nie HL, Branford-White C, Zhu LM, Zhou YT and Zheng Y (2008), Removal of $\mathrm{Cu}^{+2}$ from aqueous solution by adsorption onto a novel activated nylon -based membrane. Bioresource Technology, 99: 7954-7958

[4] Chuah TG, Jumasiah A, Azni KI and Thomas SY (2005), Rice husk as potentially low-cost biosorbent for heavy metals and dye removal an overview. Desalination 175 : 305-316.

[5] Kula I, Ugurlu M, Karaoglu H and Celik A (2008), Adsorption of Cd (II) ions from aqueous solutions using activated carbon prepared form olive stone by $\mathrm{ZnCl}_{2}$ activation. Bioresource Technology, 99: 492-501

[6] Zabaniotou A, Stavopoulos G and Skoulou V (2008), Activated carbon from olive kernels in a two stage process: industrial improvement. Bioresource Technology, 99: 320-326.

[7] Qingrong Q, Machida M and Tataumoto H (2007), Preparation of activated carbons from cattle -manure compost by zinc chloride activation. Bioresource Technology 98: 353-360.

[8] Koutcheiko S, Moreal CM, Kodoma H, McCracken T and Kotlyar L (2007), Preparation and characterization of activated derived from thermo chemical conversion of chicken manure. Bioresource Technology, 98: 2459- 2464.

[9] Srinivasan K, Balsubramaniam N and Ramkrishnan TV (1998), Studies on chromium removal by rice husk. Ind.J. Eng. Chem.Res, 39: 376-387

[10] Anna WK , Roman GS and Szymon M (2011), Biosorption of heavy metals from aqueous solutions onto peanut shell as a low cost biosorbent. Desalination, $265: 126-134$

[11] Marquez F, Montesinos CT and Rodriguez J (2001), Powdered activated carbon from sawdust. Separation Science and Technology, $36: 3191-389$

[12] Sekar M, Sakthi V and Rengarag S (2004), Kinetics and equilibrium adsorption study of lead (II) onto activated carbon prepared from coconut shell. Journal colloid and Interface Science, 279: 307-317.

[13] Issabayeva GM, Aroua KN and Sulaiman MN (2006), Removal of lead from aqueous solution on palm shell activated carbon. Bioresource Technology, 97: 2350 -2355.

[14] Imamoglu M and Tekir O, (2008), Removal of copper (II) and lead (II) ions form aqueous by adsorption on activated carbon from a new precursor hazelnut husks. Desalination, 228: 108113.

[15] Mouni L, Merabet D, Bouzaza A and Belkhiri L (2011), Adsorption of Pb (II) from aqueous solution using activated carbon developed from Apricot Stone. Desalination, 276: 148-153

[16] Bohli TA, Ouederni NF and Villaescusa I (2012), Uptake of $\mathrm{Cd}^{+2}$ and $\mathrm{Ni}^{+2}$ Metal ions from Aqueous solutions by Activated Carbons from Waste Olive Stones. International Journal of Chemical Engineering and Applications, 3(4): 232-236. 
150 Removal of Cd (II) ions from Aqueous Solution by Adsorption on Activated Carbon Prepared from Lapsi ....

[17] Muthanna JA (2011), Preparation of Activated carbons from Date Stones by Chemical Activation Method using $\mathrm{FeCl}_{3}$ and $\mathrm{ZnCl}_{2}$ as Activating Agents. Journal of Engineering, 17(4): 1007-1022.

[18] Paudel KC, Pieber K, Klumpp R and Laimer M(2003), Evaluation of Lapsi tree (Choerospondias axillaris, Roxb.) for fruit production in Nepal.

[19] Paudel KC and Parajuli DP (1999), Domestication and Commercialization of Lapsi tree: potential income source through agroforestry in the middle hills of Nepal. In Ministry of Science and Technology, Scientific World, Nepal 1(1): 116-120.

[20] Kunquan L, Zhen Z and Ye L (2010), Characterization and lead adsorption properties of activated carbons prepared from cotton stalk by one-step $\mathrm{H}_{3} \mathrm{PO}_{4}$ activation. Journal of Hazardous Materials, 181: 440 - 447.

[21] Ramos LR, Bernal LA and Acosta RI (2005), Adsorption of cadmium (II) from aqueous solution on natural and oxidized corncob. Separation and Purification Technology, 45: 41-49.

[22] Min SH, Han JS, Shin EW and Park JK (2004), Improvement of cadmium ion removal by base treatment of juniper fiber. Water Resources, 38: 1289-1295.

[23] Meitei MD and Prasad MNV (2013), Lead (II) and Cd (II) bisorption on Spirodela polyrhiza. Journal of Environmental Chemical Engineering (Press). 